\title{
EFFECTIVENESS OF A MEDICATION BOOKLET AND COUNSELING ON TREATMENT ADHERENCE IN TYPE 2 DIABETES MELLITUS PATIENTS
}

\author{
IIN PRESETIAWATI, RETNOSARI ANDRAJATI*, RANI SAURIASARI
}

Department of Pharmaceutics, Faculty of Pharmacy, Universitas Indonesia, Depok, Indonesia. Email: andrajati@farmasi.ui.ac.id

Received: 21 April 2017, Revised and Accepted: 18 August 2017

ABSTRACT

Objective: This study aimed to evaluate the effectiveness of counseling and the use of a medication booklet on the level of treatment compliance through reduced levels of glycated hemoglobin $\left(\mathrm{HbA}_{1 \mathrm{C}}\right)$ and Morisky Medication Adherence Scale (MMAS-8) scores in patients with type 2 diabetes mellitus.

Methods: This pre-experimental prospectively study was conducted at Dr. Adjidarmo General Hospital, KabupatenLebak, Banten Province, Indonesia. The study sample consisted of 30 type 2 diabetic patients who met the inclusion and exclusion criteria and who underwent a counseling intervention session and received a medication booklet. Compliance was measured against the MMAS- 8 scores and HbA $\mathrm{AC}_{1 \mathrm{C}}$ levels before the intervention and after 10 weeks of administration of counseling and receipt of the booklet).

Results: The MMAS-8 scores before and after the intervention were $2.63 \pm 1.50$ and $0.7 \pm 1.18$, respectively. The HbA ${ }_{1 C}$ levels before and after the intervention were $11.31 \pm 2.95$ and $8.12 \pm 2.79$, respectively. The measurement results for MMAS-8 and HbA 1 were analyzed using the Wilcoxon test.

Conclusions: The analysis showed a significant difference $(\mathrm{p}<0.001)$ between the $\mathrm{HbA}_{1 \mathrm{c}}$ values and MMAS- 8 scores before and after the intervention. Therefore, this study's finding indicate that the provision of counseling and an informational booklet can improve type 2 diabetes mellitus patient compliance with treatment.

Keywords: Morisky Medication Adherence Scale, Glycated hemoglobin, Compliance, Blood glucose, Type 2 diabetes mellitus, Counseling, Medication booklet.

(C) 2017 The Authors. Publishedby Innovare Academic Sciences PvtLtd. This is an open access article under the CC BY license (http://creativecommons. org/licenses/by/4.0/) DOI: http://dx.doi.org/10.22159/ijap.2017.v9s1.24_29

\section{INTRODUCTION}

The incidence of diabetes mellitus is increasing every year, worldwide. In 2013, as many as 382 million people around the world were reported to have diabetes mellitus [1]. Indonesia is ranked $7^{\text {th }}$ in the world for diabetes mellitus [2]. The national prevalence of diabetes mellitus in Indonesia is also increasing, as reported by the National Basic Health Survey in 2007 and 2013. The prevalence in 2007 was 1.1\%, and the prevalence in 2013 was $2.1 \%$ [3,4]. Diabetes mellitus is a chronic metabolic disease that requires long-term treatment and often a complex medication regimen; thus, compliance is a necessity. In 2003, the World Health Organization (WHO) reported that the mean value of patients' compliance to long-term therapy for chronic disease in developed countries was only $50 \%$, and it was even lower in developing countries [5].

The lack of compliance toward diabetes mellitus therapy could lead to chronic complications, including macrovascular and microvascular complications. Inappropriate disease management and the lack of compliance toward diabetes treatment recommendations will also reduce the effectiveness of treatment [6,7]. One of the attempts to increase patients' compliance toward treatment is to provide them with counseling and a medication booklet. When patients receive new knowledge, they are more apt to change their behavior and lifestyle. These changes could eventually increase their compliance to their ongoing treatment [8].

Glycosylated hemoglobin, known as the glycohemoglobin test $\left(A_{1 c}\right)$, is the examination used to evaluate the effect of therapy changes in comparison to baseline values obtained 8-12 weeks before treatment. A glycated hemoglobin $\left(\mathrm{HbA}_{1 \mathrm{c}}\right)$ examination could be used to manage a patient's average blood sugar level every 3 months, to observe the effectiveness of the therapy being administered, and to determine the next type of therapy that is required. A high level of $\mathrm{HbA}_{1 \mathrm{C}}$ indicates a patient's lack of compliance in managing his/her blood glucose level. The United Kingdom Diabetes Study (UKPDS) reported that a 1\% reduction in $\mathrm{HbA}_{1 \mathrm{C}}$ could reduce the complication risk by as much as $21 \%$; it could decrease the number of deaths caused by diabetes by as much as $21 \%$ and the incidence of myocardial infarction by as much as $14 \%[2,9]$. The compliance of diabetes mellitus type 2 patients was calculated by measuring the $\mathrm{HbA}_{1 \mathrm{C}}$ level before and after counseling and the distribution of a medication booklet. High compliance is shown by a low level of $\mathrm{HbA}_{1 \mathrm{C}}$

In addition to measuring the level of $\mathrm{HbA}_{1 c}$, the level of compliance to ongoing treatment of type 2 diabetes mellitus patients can also be measured using the Morisky Medication Adherence Scale (MMAS)8 questionnaire. The MMAS-8 questionnaire is an assessment tool from the WHO that has been validated and frequently used to assess the level of patient compliance in chronic diseases, such as diabetes mellitus [10]. In the present study, a treatment questionnaire, the MMAS-8 questionnaire, and $\mathrm{HbA}_{1 \mathrm{C}}$ levels were used to determine the patients' compliance level. Dr. Adjidarmo General Hospital is the only hospital owned by the government of Lebak District in Indonesia. Lebak District is the largest district in Banten Province; thus, it is expected to be capable of representing the research population. This research aimed to assess the effect of counseling and an informational booklet on type 2 diabetes mellitus patients at Dr. Adjidarmo General Hospital.

\section{METHODS}

This research study used a prospective pre-experiment design. All the participants were placed into one group and were provided with counseling and an informational booklet; thus, the study utilized a one group pre- and post-test group design [11]. In this research study, the sample was restricted to a total of 30 people. During the preliminary stage of this research (pre-test), the respondents were given the MMAS8 questionnaire and a treatment questionnaire, and their $\mathrm{HbA}_{1 \mathrm{C}}$ level 
was measured to determine their level of treatment compliance. The questionnaires' data were obtained by means of interviews. Afterward, the researcher conducted 30-minute counseling sessions with the patients and provided them with an informational booklet. 10 weeks later (post-test), the respondent are took the MMAS-8 questionnaire and the therapy questionnaire, and their $\mathrm{HbA}_{1 \mathrm{C}}$ level were measured again. The researcher conducted an interview to facilitate filling out the questionnaires.

This research study was conducted at Dr. Adjidarmo General Hospital, Lebak District, Banten Province, Indonesia. Samples were taken using consecutive sampling methods. This study assessed the impact that two independent variable risks, counseling and an informational booklet, had on the dependent variable, compliance with ongoing treatment, which can be determined through a reduction in the $\mathrm{HbA}_{1 \mathrm{C}}$ level and the MMAS-8 score. It also evaluated the impact of confounding variables, such as gender, age, duration of type 2 diabetes mellitus, education, occupation, other diseases, the type of oral hypoglycemic medication, dose regimen, other medications, side effects, herbal medications, directions, diet, smoking, and participation in sports/working out.

The questionnaire that was used in this study had undergone validity and reliability testing. Data analysis consisted of univariate and bivariate analysis. Univariate analysis was done to obtain the distribution of the patient characteristics. Bivariate analysis included Wilcoxon test, Spearman's rank correlation coefficient test, paired t-test, and Fisher's exact test.

\section{RESULTS}

\section{Characteristics of the type 2 diabetes mellitus patients}

Of the type 2 diabetes mellitus patients at Dr. Adjidarmo General Hospital that participated in this study, $77 \%$ are female. Based on data from the National Basic Health Survey (2013), the prevalence of type 2 diabetes mellitus has the tendency to be higher in females than males [4]. Research conducted by Mihardja also showed that hyperglycemic risk is two times higher in females than males [12].

In terms of age, $67 \%$ of all the respondents are over 55 . Type 2 diabetes mellitus is typically diagnosed after the age of 40 [4]. Research conducted by Mihardja stated that people ranging in age from 35 to 54 have a 4.7 times greater risk of hyperglycemia in comparison to people ranging in age from 15 to 34; people over the age of 55 have a 5.4 times higher risk of hyperglycemia in comparison to people ranging in age from 15 to 34 [12].

As many as $63 \%$ of the respondents have a low education level, ranging from no formal education to a junior high education. The level of education affects the incidence of type 2 diabetes mellitus. People with a high education level typically have more knowledge regarding health; thus, they are more aware of the need to maintain their health. As many as $90 \%$ of the respondents do not have an occupation; most of them are homemakers and most of the male respondents had retired. Homemakers do not necessarily have low physical activity; they engage in a variety of physical activities such as sweeping, cooking, and washing [13]. Sixteen of the 30 respondents (53\%) had been diagnosed with type 2 diabetes mellitus for $<5$ years. The WHO reported that the duration of diseases has a negative correlation with compliance; patients with a longer duration of type 2 diabetes mellitus tend to have less compliance to ongoing therapy [5]. This current paper is in accordance with research stating that respondents that have had type 2 diabetes mellitus for $<5$ years have a mean $\mathrm{HbA}_{1 \mathrm{C}}$ level of $10.2 \%$, whereas respondents that have had type 2 diabetes mellitus for more than 5 years have a mean $\mathrm{HbA}_{1 \mathrm{C}}$ level of $12.0 \%$.

Based on this research study's findings, $83 \%$ of the respondents have comorbidity. Elderly patients with diabetes increase the risk of complications and the risk of comorbidity [1]. Hypertension is the most common comorbidity affecting the study's respondents. Hypertension is one of the complications and risk factors of type 2 diabetes mellitus.
Several factors that affect the complications of this condition are genetics, gender, age, and blood sugar level [2]

Twenty-one of the 30 respondents (70\%) receive two types of oral hypoglycemic medication, and one respondent receives three combinations of oral hypoglycemic medication due to rejecting insulin injections. The combination of oral hypoglycemic medication that is typically used is biguanides (metformin) with sulfonylurea. This combination increases the medication's effectiveness because sulfonylurea stimulates the pancreas to secret insulin, enabling biguanides to work; thus, several medicine manufacturers have marketed this drug combination. The combination of metformin with sulfonylurea could reduce blood sugar levels more than a single medication, at both a maximum and minimum dosage [14].

This study's result showed that $93 \%$ of the respondents receive more than one oral hypoglycemic dosage regimen because most of them are taking more than two types of oral hypoglycemic medications. A simple dose medication regimen is more acceptable for type 2 diabetes mellitus patient than a complex regimen. The result of this research showed that 11 of the 30 respondents (37\%) inaccurately followed the usage direction; 3 of the 11 respondents are incorrectly using acarbose and 9 of the 11 respondents are incorrectly using glibenclamide, glimepiride, and gliquidone. Diabetes medications have different working onsets, peaks, mechanisms, and durations; thus, they have different usage directions. Patients are usually unaware of these facts; they are only aware of the need to take their medication after a meal. Several factors lead to mistakes in the directions related to medicine usage, including a lack of awareness about the directions due to not reading the medication pamphlet; an awareness of the correct directions, but the inability to follow the directions due to their complexity, feeling troubled by the side effects, and last but not least, being oblivious to consistently take the medications.

This study's result showed that 8 of the 30 respondents $(27 \%)$ experienced side effects. The most common side effect is flatulence. This could be due to the use of acarbose; one of the side effects of that medication is an increase in the frequency and intensity of flatulence (74\%), which has a tendency to subside after long-term use [15]. As many as $90 \%$ of the respondents consume other medicines in addition to the oral hypoglycemic medicine prescribed because $86.67 \%$ of these respondents suffered from other diseases; thus, this increases the amount of medicine the respondents are taking. The amount of medicine they take is also influenced by the severity of their type 2 diabetes mellitus and other comorbidities [16].

As many as $57 \%$ of the respondents stated that they managed their diet. They generally limit their consumption of glucose from sugar and carbohydrates (which in this population is rice). The sugar consumption suggestion for people with type 2 diabetes mellitus is 2 tablespoons; this is similar to the recommendation for people without diabetes, which is not more than $5 \%$ of the total calories per day. For type 2 diabetes mellitus patients, the emphasis on nutrition therapy focuses on the management of glucose, lipids, and hypertension [17].

This study's result showed that there were no changes in diet before and after the intervention. Only $47 \%$ of the respondent admitted to a lack of compliance in following the recommended diet. Respondents admitted that it is difficult to change their diets since they had been following the same one for years. The circumstances that tend to make type 2 diabetes mellitus patient violate their diet include holidays, parties or meals in a restaurant, stress, living alone, and feeling bored. Additional reasons for why following a diet is challenging include the habit of having a meal away from home (snacking), denial about the disease, a lack of understanding of the correlation between diet and the disease, incorrect information regarding the correlation between diet and disease, and a lack of social support from friends and families $[5,18]$. Only 12 of the 30 respondents (40\%) engaged in physical workouts. The previous study reported that diabetic patient compliance toward 
physical activities was 19\% [19]. In that study, compliance toward working out increased by $10 \%$ after the intervention.

In type 2 diabetes mellitus, participating in sports or working out plays a major role in controlling a patient's blood glucose level since insulin resistance decreases during workouts, insulin sensitivity increases, and membrane permeability to glucose increases. This is because when muscles are active, insulin is not needed to incorporate glucose into the cell since insulin receptor sensitivity increases; thus, glucose incorporation increases up to 7-20 times. This response only occurs while working out; it does not have a permanent or long-lasting effect. Thus, working out should be done regularly [20,21]. However, in patients with uncontrolled type 2 diabetes mellitus, working out will increase plasma glucagon and cortisol, which will eventually lead to the formation of ketone bodies that can be fatal. To prevent this from occurring, it is necessary to test blood glucose levels before and after working out.

Results showed that only $20 \%$ of the respondents smoked tobacco. Their smoking habit did not change even after the intervention. Smoking is a risk factor for type 2 diabetes mellitus. A meta-analysis reported that the risk of diabetes mellitus in smokers increase by as much as $45 \%$ compared to non-smokers. The amount of smoke being inhaled has also been found to be correlated with an increase in the risk of type 2 diabetes mellitus [22].

In general, the respondents in the present study had tried herbal medications before participating in this research. However, since they did not feel any benefit from the herbal medicines, most of them stopped consuming them. During this study, only 4 of the 30 respondents $(13 \%)$ were still consuming herbal medicines. Research conducted by the National Basic Health Survey found that $22 \%$ of diabetic patients consumed herbal medications. Other research found that $31 \%$ of patients consumed food supplement [23]. The types of herbal plants being used in India to lower blood glucose level are: Aloe vera, green pare, cinnamon, ginseng, fenugreek, shallot, and garlic. Several of these herbal plants in India are in clinical trials to lower blood glucose levels [24-27].

Compliance level of type 2 diabetes mellitus patients provided with counseling and a booklet based on decreased MMAS-8 scores At the beginning of the research study, the average MMAS-8 score was $2.6 \pm 1.5$, showing that most of the respondents had a low level of compliance. 10 weeks after undergoing counseling and receiving the medication booklet, a significant difference was found; at that point, the average MMAS-8 score decreased to $0.7 \pm 1.18$. This shows an increase in the level of compliance.

The Wilcoxon test result showed a statistically significant difference in the MMAS- 8 scores before the intervention and 10 weeks after the participants received counseling and the medication booklet $(p<0.05)$. This result shows that education in form of counseling and an informational booklet can increase the treatment compliance of type 2 diabetes mellitus patients. A graphic showing the patient compliance level percentage based on MMAS-8 scores before and after the participants received counseling and the informational booklet are presented in Fig. 1.

Compliance level of type 2 diabetes mellitus patients provided with counseling and an informational booklet based on reduction in $\mathrm{HbA}_{1 \mathrm{c}}$ levels

At the beginning of the research study, the mean value of the respondents' compliance level based on $\mathrm{HbA}_{1 \mathrm{C}}$ was $11.3 \pm 2.95 \%$. Twenty-nine of the 30 respondents (97\%) had an $\mathrm{HbA}_{1 \mathrm{C}}$ level above $7 \%$. After undergoing counseling and receiving the informational booklet, the mean value of compliance level was $8.1 \pm 2.79$. The average reduction of $\mathrm{HbA}_{1 \mathrm{C}}$ level was $3.19 \pm 2.42 \%$. The reduction of the $\mathrm{HbA}_{1 \mathrm{C}}$ level to $8.1 \pm 2.79 \%$ meant that the patient was still in the diabetic category since the normal level of $\mathrm{HbA}_{1 \mathrm{C}}$ is $<6.5 \%$. This could be because the counseling session and the booklets were only given during the 10 -week period after the initial intervention. The Wilcoxon test was conducted to determine the difference between the $\mathrm{HbA}_{1 \mathrm{c}}$ level before the intervention and 10 weeks after the participants underwent counseling and received the booklet. The result shows that there is a statistically significant difference in the $\mathrm{HbA}_{1 \mathrm{C}}$ levels $(\mathrm{p}<0.05)$. As shown in Table 1 , as many as 28 of the 30 respondents had a reduction of their $\mathrm{HbA}_{1 \mathrm{C}}$ level; however, the levels of 19 of the respondents were still in the abnormal category $(>6.5)$ and 9 had their abnormal $\mathrm{HbA}_{1 \mathrm{C}}$ level reduced to a normal level. The paired t-test results shown a statistically significant difference between the $\mathrm{HbA}_{1 \mathrm{C}}$ level before the intervention and 10 weeks after the participants received counseling and an informational booklet $(\mathrm{p}=0.001)$.

Bivariate analysis between $\Delta \mathrm{HbA}_{1 \mathrm{c}}$ with anthropometric, sociodemographic, clinical, and lifestyle variables

Bivariate analysis was conducted using Fisher's exact test to examine the unpaired categorical scale comparative hypothesis, and the expected count was $<5$ [7]. In the present study, age variables had no effect on the compliance level $(\mathrm{p}=0.540)$.

Education level and occupation were the sociodemographic variables analyzed in the present study. Based on the Fisher's test result, education level and occupation had no impact on the compliance level $(\mathrm{p}=1.000)$. The following clinical variables were also analyzed: Type 2 diabetes mellitus duration, comorbidities, the amount of oral hypoglycemic medication, the amount of the dosage regimen, the usage directions, and other prescribed medicines. The Fisher's exact test results showed that these clinical variables had no impact on the compliance level $(p=1.000)$. The following lifestyle variables were analyzed: Diet, herbal medication, smoking, and participating in sports or working out. The Fisher's exact test results showed that these lifestyle variables had no impact on the compliance level $(\mathrm{p}=1.000)$.

Bivariate analysis of the differences between $\Delta \mathrm{HbA}_{1 \mathrm{C}}$ and $\Delta$ MMAS-8 A normality test was done to evaluate the $\mathrm{HbA}_{1 \mathrm{C}}$ levels and MMAS-8 scores. The result showed that both the $\mathrm{HbA}_{1 \mathrm{C}}$ level and the MMAS- 8 data were abnormal. To examine the correlation between the numerical correlative hypotheses and the abnormal data distribution, Spearman's

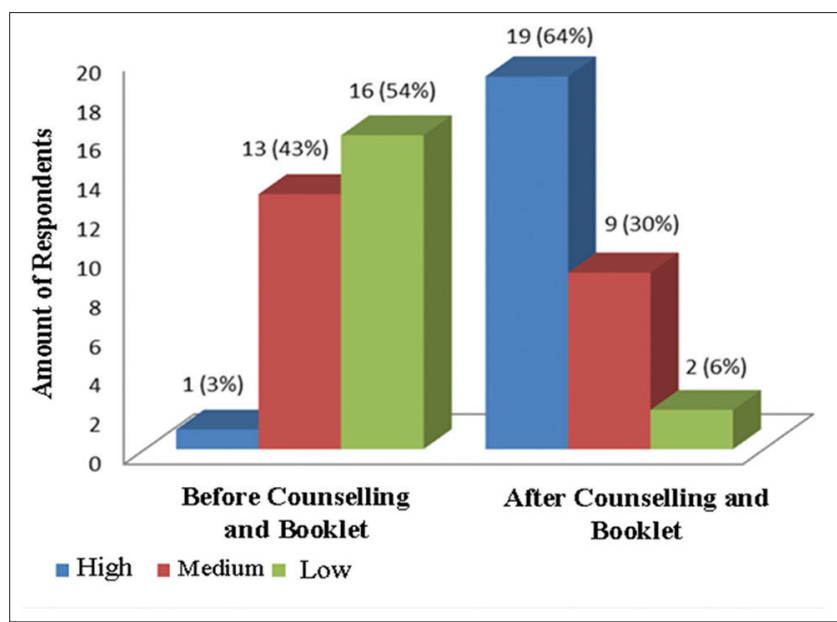

Fig. 1: Compliance level graphic based on MMAS-8 scores before and after counseling and receiving an informational booklet

Table 1: $\mathrm{HbA}_{1 \mathrm{c}}$ level before the intervention and 10 weeks after type 2 diabetes mellitus patients who underwent counseling and receiving an informational booklet

\begin{tabular}{llll}
\hline HbA $_{\mathbf{1 C}}$ level & Before $\mathbf{X} \pm \mathbf{S D}$ & After $\mathbf{X} \pm$ SD & Delta $\mathbf{X} \pm$ SD \\
\hline $\mathrm{HbA}_{1 \mathrm{C}}$ level $(\%)$ & $11.31 \pm 2.95$ & $8.12 \pm 2.79$ & $3.19 \pm 2.42^{*}$ \\
MMAS-8 scores & $2.63 \pm 1.50$ & $0.7 \pm 1.18$ & $2 \pm 1.2^{* *}$ \\
\hline $\mathrm{X} \pm S D ;$ mean \pm san
\end{tabular}


rank correlation coefficient test was conducted. A positive correlation between the $\mathrm{HbA}_{1 \mathrm{c}}$ level and MMAS- 8 was found with $\mathrm{r}=0.432$ and $p=0.001$. The $r=0.432$ value shows that there is enough correlation between these two factors since an $\mathrm{r}$ value close to 0 represents a weak correlation [28]. The $\mathrm{p}=0.001$ result shows that there is a significant correlation between the $\mathrm{HbA}_{1 \mathrm{C}}$ level and the MMAS- 8 score.

\section{DISCUSSION}

The respondents' compliance level was measured using MMAS-8, the WHO assessment tool that has been validated and frequently used to assess the compliance level of patients toward their medications. The MMAS-8 questionnaire addresses three aspects of patient compliance: Obliviousness to the requirements of consuming medication, intentionally stopping the medication without the medical team noticing, and the ability to continue consuming the medicine [29]. Counseling was done meticulously taking into account the packaging of the information, the condition of the respondents (socioculture), and the time and space in which it occurred [30]. The information given to the respondents was adjusted according to each patient's condition; if too much information is given during the counseling session, the respondents could become bored. Through the counseling, the researcher provided suggestions for how to overcome the three aspects addressed in the MMAS- 8 questionnaire. The researcher gave recommendations to help the respondents remember to consume their medication, such as always take the medication with you wherever you go, always store a supply of the medication in your car, and set an alarm on your mobile phone to remind yourself to take the medication. During the counseling session, the importance of compliance to taking type 2 diabetes mellitus medications and the possible risk of complications were emphasized; moreover, the respondents needed to be motivated to maintain their therapeutic treatment regime. The disadvantage of the MMAS- 8 questionnaire is that the respondents' answers could be subjective; they might not necessarily reflect their actual behavior. Before the intervention, as many as $54 \%$ of the respondents had a low compliance level. Based on the results of the interview, some of the reasons for the lack of compliance included the inability to obtain the medicine, the amount of the oral hypoglycemic medicine was insufficient, fasting, and forgetfulness. Some of these reasons are similar to those reported by Keban, Mustopa, and Purnomo: Forgetfulness, intentionally not taking the medication, unaware of the directions, relying on other people, the dose was insufficient, did not receive the medicine, and the medicine was too expensive [18].

This study's result shows that counseling and the informational booklet were effective in increasing patient compliance. Research conducted by the Diabetes among Latinos Best Practices Trial in 2009 also reported a higher reduction of HbA1C levels in the group receiving counseling in comparison to the group that only received medication. Other research has reported that consultation with a pharmacist at every appointment could increase the effectiveness of a blood glucose control program [31]. In a review of five studies, Lindenmeyer found that educational interventions by a pharmacist could increase diabetic patient compliance toward medication [32].

The present study's results showed also that gender has a weak correlation with the reduction of the HbA1C level. This finding is in accordance with the research conducted by Adisa, which found that males have a tendency to forget to consume their medication, which impacts their HbA1C level [33]. Further result, which shows significant correlation between the HbA1C level and the MMAS-8 score, is in accordance with the findings reported by Al-Qazaz, which found a statistically significant correlation between $\mathrm{HbA}_{1 \mathrm{C}}$ level and MMAS-8 [34]. The result of this present research study shows that counseling and the informational booklet for 10 weeks could decrease the $\mathrm{HbA}_{1 \mathrm{C}}$ level and increase the compliance level significantly. The increase in compliance can be seen from the reduction of the MMAS8 score.

\section{CONCLUSION}

The improvement in the compliance level of type 2 diabetes mellitus patients is shown by the reduction in their $\mathrm{HbA}_{1 \mathrm{C}}$ levels and the reduction in their MMAS-8 scores. There is a positive correlation between gender and the decrease in the $\mathrm{HbA}_{1 \mathrm{C}}$ level. The reduction of $\mathrm{HbA}_{1 \mathrm{C}}$ levels is higher in females than males. Further research with a larger number of respondents could be conducted to better represent the type 2 diabetes mellitus population. Research covering a longer period is also required. In addition, further research comparing a control group with an intervention group is needed, and more specific research regarding the correlation between gender and the reduction in $\mathrm{HbA}_{1 \mathrm{C}}$ level is required.

\section{REFERENCES}

1. International Diabetes Federation. Diabetes Atlas. $6^{\text {th }}$ ed. Brussels: IDF Executive Office; 2013. Available from: http://www.idf.org/ diabetesatlas.

2. PB PERKENI since the year meetingi. Konsensus Pengelolaan Dan Pencegahan Diabetes Melitus Tipe 2 di Indonesia. Jakarta: Perkumpulan Endokrinologi Indoesia; ; 2011

3. Riset Kesehatan Dasar. Badan Penelitian dan Pengembangan Kesehatan. Jakarta: Departemen Kesehatan, Republik Indonesia; 2007.

4. Riset Kesehatan Dasar. Badan Penelitian dan Pengembangan Kesehatan. Jakarta: Departemen Kesehatan, Republik Indonesia; 2013.

5. World Health Organization. Adherence to Long-Term Therapies: Evidence for Action. Geneva: World Health Organization; 2003.

6. Departemen Kesehatan RI. Pharmaceutical care untuk penyakit diabetes mellitus. Jakarta: Direktorat Bina Farmasi Komunitas Dan Klinik Direktorat Jenderal Bina Kefarmasian Dan Alat Kesehatan; 2005.

7. Adisa R, Fakeye TO, Fasanmade A. Medication adherence among ambulatory patients with Type 2 diabetes in a tertiary healthcare setting in southwestern Nigeria. Pharm Pract (Granada) 2011;9(2):72-81.

8. Siregar CJ, Kumolosasi E. Farmasi Klinik Teori dan Penerapan. Jakarta: EGC; 2006.

9. Stratton M, Adler AI, Neil HA, Matthews DR, Manley SE, Cull CA, et al. Association of glycaemia with macro vascular and micro vascular complications of Type 2 diabetes (UKPDS 35): Prospective observational study. Br Med J 2000;321(7258):405-12.

10. Morisky DE, DiMatteo MR. The morisky 8-item self-report measure of mediacation-taking behavior (MMAS-8). J Clin Epidemiol 2011;64:262-3.

11. Notoatmodjo S. Metodologi Penelitian Kesehatan. Jakarta: Rineka Cipta; 2011.

12. Mihardja L. Associated factors of blood glucose control in diabetes mellitus patients in urban areas of Indonesia. Majalah Kedokt Indones 2009;59(9):418-24.

13. Trisnawati SK, Setyorogo S. Risk factors of type 2 diabetes mellitus in primary health care center of Cengkareng West Jakarta in 2012. J Ilmiah Kesehatan 2013;5(1):6-11.

14. Waspadji S. Diabetes Melitus, Penyulit Kronik dan Pencegahannya. Jakarta: FKUI; 2013.

15. Lacy CF, Armstrong LL, Goldman MP, Lance LL. Drug Information Handbook. $14^{\text {th }}$ ed. North American: Lexi Comp; 2011.

16. Rubin RR. Adherence to pharmacologic therapy in patients with Type 2 diabetes mellitus. Am J Med 2005;118 Suppl 5A:27S-34.

17. Sukardji K. Penatalaksanaan Gizi Pada Diabetes Melitus. Jakarta: FKUI; 2013.

18. Keban SA, Purnomo LF, Mustofa M. Evaluation of Pharmacist education to type 2 diabetes mellitus patients in Dr. Sardjito Hospital Yogyakarta. J Ilmu Kefarmasian Indones 2013;11:45-52.

19. Delamanter AM. Improving patient adherence. Clin Diabetes J 2006;24(2):771-7.

20. Wolfe RR. Metabolic interactions between glucose and fatty acids in humans. Am J Clin Nutr 1998;67 3 Suppl:519S-26.

21. Indiyani P, Supriyatno H, Santoso A. The effect of aerobic physical gymnastic training in reducing blood glucose level in type 2 diabetes mellitus patients in primary health care center. Bukateja Purbalingga. Media Ners 2007;1(2):89-99.

22. Willi C, Bodenmann P, Ghali WA, Faris PD, Cornuz J. Active smoking and the risk of Type 2 diabetes: A systematic review and meta-analysis. JAMA 2007;298:2654-64

23. American Diabetes Association. Standards of medical care in diabetes--2014. Diabetes Care 2014;37 Suppl 1:S14-80. 
24. Chawla R, Thakur P, Chowdhry A, Jaiswal S, Sharma A, Goel R, et al. Evidence based herbal drug standardization approach in coping with challenges of holistic management of diabetes: A dreadful life style disorder of $21^{\text {st }}$ century. J Diabetes Metab Disord 2013;12(1):35.

25. Gupta PD, De A. Diabetes mellitus and its herbal treatment. Int J Res Pharm Biomed Sci 2012;3(2):706-21

26. Huseini HF, Kianbakht S, Hajiaghaee R, Dabaghian FH. Antihyperglycemic and anti-hypercholesterolemic effects of Aloe vera leaf gel in hyperlipidemic Type 2 diabetic patients: A randomized doubleblind placebo-controlled clinical trial. Planta Med 2012;78(4):311-6.

27. Ngo MQ, Nguyen NN, Shah SA. Oral Aloe vera for treatment of diabetes mellitus and dyslipidemia. Am J Health Syst Pharm 2010;67(21):1804-11.

28. Al-Qazaz HK, Hassali MA, Shafie AA, Sulaiman SA, Sundram S, Morisky DE. Use of 8-item morisky medication adherence scale for the assesment of medication adherence in Type 2 diabetes mellitus. Value Health 2010;13(7):A528
29. Hartono B. Promosi Kesehatan di Puskesmas dan Rumah Sakit. Jakarta: Rineka Cipta; 2010.

30. Suppapitiporn S, Chindavijak B, Onsanit S. Effect of diabetes drugc ounseling by pharmacist, diabetic disease booklet and special medication containers on glycemic control of Type 2 diabetes mellitus: A randomized controlled trial. J Med Assoc Thai 2005;88(4):S134-41.

31. Lindenmeyer A, Hearnshaw H, Vermeire E, Van Royen P, Wens J, Biot Y. Interventions to improve adherence to medication in people with Type 2 diabetes mellitus: A review of the literature on the role of pharmacists. J Clin Pharm Ther 2006;31(5):409-19.

32. Dahlan S. Statistik Untuk Kedokteran dan Kesehatan. $5^{\text {th }}$ ed. Jakarta: Salemba Medika; 2011.

33. Krousel-Wood M, Islam T, Webber LS, Re RN, Morisky DE, Muntner P. New medication adherence scale versus pharmacy fill rates in seniors with hypertension. Am J Manag Care 2009;15(1):59-66.

34. Sarwono J. Metode Penelitian Kuantitatif dan Kualitatif. Yogyakarta: Graha Ilmu; 2006. 